\title{
Collusion and conspiracy in colonial Natal: \\ A case study of Reynolds Bros and indentured abuses 1884-1908
}

\section{Duncan Du Bois*}

\section{Introduction}

By 1904, there were over 1300 employers of indentured Indians in Natal. Besides sugar plantations and other agricultural pursuits, the coalfields, Durban Corporation and the Natal Government Railways also made extensive use of indentured labour. ${ }^{1}$ While disease and epidemics took their toll on indentured lives, ${ }^{2}$ the relatively high incidence of suicides should have provoked concern. Thanks to the persistence and diligence of James Polkinghorne, the Protector of Indian Immigrants, the high death rate on estates belonging to Reynolds Bros in the Umzinto district was officially investigated ${ }^{3}$ and subsequently resulted in a change in the senior management of the company.

International economics influenced labourers' circumstances. Falling prices, the result of an over-supply of sugar on world markets, saw planters like the Reynolds brothers strive to maintain profit margins by exploiting their indentured labour to the maximum. ${ }^{4}$ This was done by extending the length of the working day, particularly during the milling season. As Peter Richardson has remarked: "Such extensions were over and above those secured by penal provisions which permitted planters to extend the length of contracts beyond the stipulated period for non-fulfilment of conditions." Overworking, manipulation of wages and poor conditions were constant features of the period of price depression and low

The author of Labourer or Settler? Colonial Natal's Indian Dilemma, (Just Done Productions, Durban, 2011), Duncan Du Bois successfully completed a DPhil dissertation entitled "Sugar and Settlers: The Colonisation of the Natal South Coast 1850-1910", at the University of KwaZulu Natal in 2013.

How to cite this article:

Du Bois D. Collusion and conspiracy in colonial Natal: A case study of Reynolds Bros and indentured abuses 1884. Historia. 2015; 1(1), Art. 17 pages.

http://dx.doi.org/10.17159/2309-8392/2015/v60n1a6

1. S. Bhana and A. Bhana, 'An Exploration of the Psycho-historical Circumstances surrounding Suicide among Indentured Indians 1875-1911", in S. Bhana (ed.), Essays on Indentured Indians in Natal (Peepal Press, Leeds, 1991), p 141.

2. For statistics on the admission of Indians to hospitals in Natal and the reasons for those admissions during the period 1884-1910, see SA Medical Journal, 65, 21 January 1984.

3. Bhana, Essays on Indentured Indians, pp 141-144. The death rates per thousand Indians in Natal for the years 1902 to 1905 were: 48, 40, 34 and 35,5 deaths. On Reynolds Bros Estates during the same period they were: 115, 62, 64 and 93 deaths. The only other official investigation of a specific sugar estate took place in 1862. Henry Shire of Melkhout Kraal Estate was subjected to an inquiry on the grounds of ill-treatment of his indentured labourers.

4. P.R. Warhurst, "Obstructing the Protector", Journal of Natal and Zulu History, 7, 1984, p 32. 
yields. ${ }^{5}$ In his report for 1905 , Polkinghorne, the noted specifically that "the one condition which is not strictly observed is the hours of labour". 6

Indentured labourers, as Maureen Swan has argued, were essentially hostages to a "material and ideological matrix". ${ }^{7}$ Charles Reynolds made that clear during the Reynolds inquiry in 1906 when he stated that Indians had not been brought to Natal for the purpose of "doing as little work as possible and having an easy time". ${ }^{8}$ Added to that outlook was the prevailing racial hierarchy which, as Tim Keegan reminds us, was "present from the beginnings of settlement at the Cape". European colonisers brought with them "stereotypes and prejudices" and "an inherent ethnocentrism". ${ }^{9}$ Given the prevailing settler mindset which disdained Indians and were reluctant to accept them as fellow-settlers, it followed that settler attitudes to the condition and plight of Indians as indentured labourers were hardly likely to register much concern in terms of social conscience. Indians in Natal qualified merely as "exogenous others", a term Lorenzo Veracini has used to refer to the "triangular relationship" which they formed together with settlers and indigenous peoples. ${ }^{10}$

The availability and reliability of indentured labour was such that despite the clamour of white settlers against Indians as settlers, ${ }^{11}$ their services came to be seen as indispensable to the progress of Natal. As late as 1909, Robert Archibald, a senior member of the legislative assembly for Alexandra County on the South Coast, stated in evidence to the Clayton Commission that "stoppage of indenture would mean absolute ruin" to the sugar industry. ${ }^{12}$ That being the case, the focus of this paper is to highlight the inconsistency, if not the double-standards, which prevailed in official attitudes towards the treatment of indentured Indians in Natal.

\section{Web of collusion}

In 1872 the government of India and the British Colonial Office saw fit to suspend indentured immigration to Natal following complaints of ill-treatment made by a small number of Indians who returned to India after completing their indentured contracts. $^{13}$ Among the recommendations of the Coolie Commission which investigated those complaints, was the abolition of flogging, improved medical

5. P. Richardson, "The Natal Sugar Industry in the Nineteenth Century", in W. Beinart, P. Delius and S. Trapido (eds), Putting a Plough to the Ground: Accumulation and Dispossession in Rural South Africa 1850-1930 (Ravan Press, Johannesburg, 1986), p 155.

6. Quoted in Indian Opinion, 4 August 1906.

7. M. Swan, "Indentured Indians: Accommodation and Resistance 1890-1913", in Bhana, Essays on Indentured Indians, p 132.

8. Warhurst, "Obstructing the Protector", p 37.

9. T. Keegan, Colonial South Africa and the Origins of the Racial Order (David Philip, Cape Town, 1996), p 281.

10. L. Veracini, Settler Colonialism (Palgrave McMillan, Basingstoke, 2010), p 18.

11. See Du Bois, Labourer or Settler? pp 89-112.

12. Pietermaritzburg Archives Repository (hereafter PAR), CSO 1878, 5276, 1909, pp 59-60. The commission, however, did recommend the discontinuation of indentured labour.

13. Natal Government Notice No. 205, 1872. Complaints of ill-treatment, which included flogging, were made by 228 Indians returning aboard the Red Riding Hood. See Natal Mercury, 12 August 1871. Faults in the indenture system also occurred in Mauritius, Fiji and British Guiana. See K. Saunders (ed.), Indentured Labour in the British Empire 18341920 (Croon Helm, London, 1984). 
services and the appointment of a Protector of Indian Immigrants. ${ }^{14}$ Those measures were seen as essential to placate the Indian government which was alarmed at the reports of conditions in Natal. ${ }^{15}$ But as the authors Desai and Vahed have remarked, while the "Protector was an important cog in the indentured enterprise", his role was "less to protect the indentured than project the impartiality of the state". ${ }^{16}$ Thus, the Protector, wittingly or unwittingly, played a sanitising role as far as the humanitarian aspect of indenture was concerned. That, in turn, secured the planters' interests of an uninterrupted supply of indentured immigration. ${ }^{17}$

A further addition to the bureaucratic management of indentured labour, as a result of the recommendations of the Coolie Commission, was the establishment of the Indian Immigration Trust Board (IITB). In terms of Law 20 of 1874 the board comprised the Protector, the colonial secretary and one other official. Its chief function was to undertake "the receipt, disbursement and administration of all moneys for purposes of Indian immigration". ${ }^{18}$ In 1880 the structure of the IITB was expanded to include two non-government members who were invariably employers of indentured labour. ${ }^{19}$ Following the onset of the responsible government dispensation, the board ceased to be a government agency when, in terms of Act 34 of 1895, it became an employers' agency with voting rights vested exclusively with employers. ${ }^{20}$ Independent of the government, the membership of the IITB was increased to seven. As such, it became an instrument in the hands of large employers of indentured labour, ${ }^{21}$ some of whom were politicians.

On 19 December 1895, Frank Reynolds of Reynolds Bros sugar estates was elected to the IITB. He remained a member until 1904 when he was replaced by his brother, Charles. When Charles resigned in 1907, Frank returned to the IITB. ${ }^{22}$ Frank Reynolds' colonial political career between 1894 and 1906 saw him serving in the legislative council, to which he was appointed by the governor, and the legislative assembly to which he was elected by the voters of Alexandra County. In December 1895 he joined the board of directors of Natal Estates which, through the efforts of David Don and Marshall Campbell of Victoria County, had acquired control over several pioneer sugar estates on the North Coast. ${ }^{23}$ Among those sugar planters who served on the IITB were Henry Binns, Ernest Acutt and Sir James Liege Hulett of the North Coast and St George Arbuthnot of the South

14. Natal Government Gazette, Vol. XXIV, No. 1373, 17 September 1872.

15. Government of India, Department of Emigration, to Secretary of State Kimberley, 10 May 1872. Cited in the Coolie Commission Report, Natal Government Gazette, Vol. XXIV, No. 1373, 17 September 1872.

16. A. Desai and G. Vahed, Inside Indian Indenture: A South African Story 1860-1914 (HSRC Press, Cape Town, 2010), p 95.

17. As Natal Mercury editor and prominent political figure, John Robinson, stated: "We must always walk with the fear of the Indian authorities in our eyes" - 7 June 1877.

18. Natal Government Gazette, Vol. XXVI, No. 1453, 20 January 1874.

19. Government Notice, No. 301, 1880.

20. Natal Government Gazette, Vol. XLVII, No. 2751, 27 August 1895. The Protector and one other nominated government official also had representation on the Board.

21. Reynolds Bros with 752 indentured labourers in 1895, was the largest employer on the South Coast. See Natal Government Gazette, Vol. XLVIII No. 2736, 21 May 1895.

22. Natal Government Gazette, No. 3467, 3 December 1907.

23. Indian Immigration Trust Board, 14th Annual Report, 9 December 1896, p 1; Natal Mercury, 1 December 1896. Campbell was also a member of the Natal Legislative Council. 
Coast. ${ }^{24}$ Binns and Hulett were prominent colonial politicians. Before serving as prime minister from September 1897 until his death in June 1899, Binns was chairman of the IITB. Although not a member of the IITB, the senior political member for Alexandra County, Robert Montgomery Archibald, as noted earlier, not only endorsed the continuation of indentured immigration, but, as will be noted later, was uncritical about the treatment of indentured labour on sugar estates in his constituency.

Collusion in the Umzinto case extended to the district medical officer and the resident magistrate. Medical officers fell under control of the IITB. ${ }^{25}$ The words of Umzinto medical officer, Dr Abel Jean Antonie Rouillard, to the 1906 Reynolds Inquiry confirm that:

I have got two masters. I have the Immigration Board and the Protector of Indians. I also have on the other side the employers of labour....It is my duty to keep on good terms with them for my own benefit. ${ }^{26}$

In a letter to Charles Reynolds dated 14 September 1904 concerning Reynolds' failure to issue dholl to his labourers, Alexandra County's resident magistrate, James McLaurin wrote: "We quite understand one another and it will indeed be a great joy to me should there never be any further occasion for me to trouble you." ${ }^{27}$ The extent of McLaurin's obeisance to Reynolds' interests is elaborated upon in the discussion of the Reynolds inquiry and serves to underline the relevance of Leonard Thompson's observation that "magistrates dared not flout the interests of the prosperous sugar planters, the social lions of their districts". ${ }^{28}$ Moreover, as will be noted, the silence of the press, including Gandhi's Indian Opinion, on the ill-treatment of indentured labourers, constituted a substantial part of the web of collusion.

Despite the humanitarian recommendations of the Coolie Commission, the structure of official and civil society was virtually impervious for an indentured labourer seeking redress for injury or ill-treatment. Sections 30 to 34 of Law 25 of 1891 provide a case in point. A labourer seeking to lodge a complaint with a magistrate or the Protector first had to obtain a ticket of leave of absence from his employer. Without that, he faced a ten shilling fine or a week's imprisonment with hard labour. Even absence through illness resulted in a deduction of four pence per day from his wages (section 34 ). ${ }^{29}$ Thus, employers were the gatekeepers and arbiters of the access indentured labourers had to legal redress. As the Bhanas have mentioned, the "physical and social well-being [of indentured Indians] were totally in the hands of the employer."

The return of criminal cases adjudicated by acting resident magistrate for Alexandra County, William Rose Gordon, in July 1884 provides a snapshot view of

24. See PAR CSO 954, No. 4409, 19 March and 18 April 1884; Annual Reports of the IITB 1995-1904; Natal Mercury, 19 December 1904.

25. Indian Opinion, 30 August 1908.

26. Bhana, Essays on Indentured Indians, p 145.

27. PAR, CSO 2854, No. 7790.

28. L. Thompson, 'Indian Immigration into Natal 1860-1872,' (MA thesis, Unisa, 1938), pp 100101.

29. Indian Opinion, 3 October 1908.

30. Bhana, Essays on Indentured Indians, p 137. 
the extent of brutality and disregard for basic rights that existed within the indentured system. Of 28 cases listed, nine involved assault by whites on Indians. Several of those cases concerned the non-payment of wages in which the employers were found guilty and paid small fines ranging from ten shillings to just under £2. Charges against Indian labourers ranged from misconduct and disobedience to absence without a pass. ${ }^{31}$ What the case return does not show is the number of instances where indentured labourers were denied access to the magistrate by their employers through intimidation and outright refusal. At the same time, the mild punishments handed down to white employers by the magistrate indicated a degree of collusion with the leading elements of settler society.

With the exception of two Protectors of Indian Immigrants, Louis Mason and James Polkinghorne, colonial officials were not impartial towards Indians in the execution of their duties. Moreover, during the latter part of the colonial period there appeared to be a cordon sanitaire cast around the treatment of indentured labour which, as outlined above, embraced magistrates, county medical officers, political representatives, the Indian Immigration Trust Board and the press.

\section{Indifference to the welfare of indentured labourers}

Throughout the period of indenture, as official reports and commissions observed, the housing provided by employers was appalling. ${ }^{32}$ Generally that accommodation comprised of wattle and daub hovels partitioned into small rooms. Cooking, washing and sanitation facilities were non-existent. In 1911, the final year in which indentured labourers arrived, the Protector of Indian Immigrants was still urging employers to provide wash-houses for women so they could at least enjoy some privacy. ${ }^{33}$ The Mercury in 1881 highlighted the poor accommodation of indentured labourers on sugar estates in reporting the death of two Indian children when a hut caught fire on an Equeefa estate. "The wonder is that as there are so many coolie houses burnt down being made of such combustible material, there is not greater loss of life," the paper stated in an editorial. ${ }^{34}$ The 1906 Reynolds Inquiry found that barracks on the Reynolds estates were improperly built. There was no lining of the corrugated iron sheeting. As a result there was no protection from heat or cold. Latrine facilities were crude or non-existent. ${ }^{35}$

Faecal discharge into coastal streams as a result of the absence of latrines at the barracks of Indian labourers on sugar estates was found to be a major cause of pollution by a commission of enquiry in 1881. Equeefa and Umzinto were among the estates visited by the commission which noted that labourers relieved themselves on the banks of streams. Consequently, it recommended that labourers' huts should not be built closer than 300 feet from a stream and that

31. PAR, CSO 1005, No. 3904, 1884.

32. There was a general lack of knowledge about the indentured labour dispensation to which Natal committed itself in 1859 specifically as regards accommodation. Apart from an enquiry by Sidney Platt of Isipingo on this subject, concern for the residential welfare of indentured labourers did not feature in planters' correspondence. PAR, CSO 119, 38, 8 January 1860; Du Bois, "Sugar and Settlers", p 26.

33. Desai and Vahed, Inside Indian Indenture, pp 119-121.

34. Natal Mercury, 17 June 1881.

35. Bhana, Essays on Indentured Indians, p 146. 
latrines should be provided. The increase in cases of sickness and mortality was attributed to faecal pollution of streams. ${ }^{36}$

\section{The Wragg Commission 1885-87}

The practice of flogging was prohibited by the Coolie Commission of 1872 yet that did not mean an end to human rights abuses inflicted on indentured labourers by sirdars and employers. Indicative of the settler preference for harsh punishment was a series of petitions presented to the legislative council in 1883 calling for magistrates to be empowered to order whipping as a punishment for recalcitrant Africans. Two of the petitions came from residents of Weenen County. The third petition was submitted by Charles Reynolds (son of Thomas Reynolds) and 52 others of Alexandra County. ${ }^{37}$ At that time magistrates had to seek the governor's assent for whipping as a punishment. In motivating the petitions, Thomas Reynolds, a wealthy owner of extensive sugar estates and South Coast member of the legislative council (MLC), said that to do away with flogging was to show ignorance in how white people needed to deal with "native races" ${ }^{38}$ Exploitation of labour in order to realise optimum financial returns was fundamental to the way Reynolds and his sons, Charles and Frank, ran their estates. Even before the Wragg Commission began its inquiry in 1885, the Protector of Indian Immigrants, Louis Mason, was aware of human rights abuses on the Reynolds' Umzinto estate. In 1884 and 1885, one of the overseers, C. Edgar, was twice convicted of assault, yet the Reynolds declined to dismiss the man. ${ }^{39}$ Mason was also aware that the Reynolds sugar interests were the most extensive and affluent on the South Coast. ${ }^{40}$

Thomas Reynolds himself was opposed to the establishment of the Wragg Commission of Inquiry into Indian immigration..$^{41}$ In his view it would be "as rotten an egg as ever laid" which would not produce any benefit. Instead, Indians should be compelled to indenture for two terms, "kept in a state of continued activity ... and then allowed to go back" to India. ${ }^{42}$ His disapproving and critical attitude was

36. Government Notice, No. 388, 9 September 1881. The commission was also critical of the discharge of "dunder" and bagasse from sugar mills into streams. The acting resident magistrate for Alexandra County, William Rose Gordon, complained about the pollution of streams in his report for 1884. See Natal Blue Book, 1884, p B59.

37. Natal Legislative Council, Votes and Proceedings, XXXIV, 1883, p 298; pp 311-312.

38. Debates of the Legislative Council, VI, 1883, 31-36. John Robinson and James Hulett were among the prominent public representatives who favoured flogging. Only Harry Escombe, a lawyer by profession, disagreed. According to Pete and Devenish, "white settlers in colonial Natal seemed to possess an almost blind faith in the power of corporal punishment to control black offenders". See S. Pete and A. Devenish, "Flogging, Fear and Food: Punishment and Race in Colonial Natal", Journal of Southern African Studies, 31, 1, March 2005, p 5.

39. Warhurst, "Obstructing the Protector", p 32.

40. In 1883, T. Reynolds \& Sons invested $£ 17000$ on a new mill and estate between Equeefa and Umzinto. See Natal Blue Book, 1883, p GG44.

41. The commission under the chairmanship of Natal Supreme Court Judge Walter Wragg was appointed in 1885 to enquire into and report on Indian immigration laws and regulations and to devise means to be adopted to bring the Indian population under more effective control and supervision.

42. Debates of the Legislative Council, VII, 1884, p 280. Very few Indians re-indentured after serving five years. In 1883, for example, not a single one re-indentured out of 4548 who obtained discharge certificates. See Natal Blue Book, 1883, p FF47. 
reflected in his son's submissions to the commission. Charles described the visits to his estates by the Protector as "obnoxious" because they led to insubordination. As a result, he had more labourers punished in one month than he had in the six months when the Protector did not visit. He objected to being asked to remove himself from a meeting addressed by the Protector claiming that such a request was "impertinent". In Charles Reynolds' view the law did not provide sufficient punishment for absentees who ought to be sentenced to terms of imprisonment with a spare diet. ${ }^{43}$ Overall, he felt "coolies are much too protected now and ... the protection system is overdone". Like his father, he felt that all Indians should be kept in agricultural pursuits and not allowed to own stores. ${ }^{44}$ Despite his hard-line views, the commission saw no ill in Charles Reynolds' refusal to withdraw while the Protector was addressing his labourers and expressed pleasure at the "arrangements for their comfort and welfare". ${ }^{45}$ In so doing the Wragg Commission unwittingly drew a cordon sanitaire around the Reynolds estates which facilitated their exploitation of indentured labour for the next twenty years. ${ }^{46}$

As a result of the absence of latrines, the commission found ample evidence of water pollution from human excrement on the Reynolds Umzinto Number One estate. Resident magistrate Gould Arthur Lucas described the stream pollution on the Reynolds estates as "perfectly pestiferous". ${ }^{77}$ Similar conditions prevailed on the Number Two estate, Equeefa estate, Maryville and Cowick estates. On Cowick, the owner, Andrew Sinclair, was found to make up his own prescriptions to dispense to the sick. His wages book was a shambles. Huts on Maryville were unfit for human occupation, many of them made of grass. Only John Bazley's Nil Desperandum estate was found to be satisfactory in all respects. ${ }^{48}$ The commission noted that attempts to curb the pollution of streams had been brought before the legislative council in 1882, 1883 and 1884 but had been abandoned after amendments removed mention of the coast lands. Even the commission's own recommendation for legislation to address the pollution of streams produced opposition from James Renault Saunders, who, as a commissioner, appended a minority report. In it he argued that criticism of the water supply contradicted the commission's key finding that the health of the Indian population was generally good. ${ }^{49}$

\section{Ongoing human rights abuses}

The findings of the Wragg Commission and its recommendations did not materially improve the conditions of the indentured or put an end to abuses on plantations. The high death rate and incidence of suicides emphasised that reality. ${ }^{50}$

43. A spare diet comprised one bowl of unsalted rice a day.

44. Wragg Commission Report in Y.S. Meer, Documents of Indentured Labour in Natal 18511917 (Institute of Black Research, Durban, 1980), pp 420-421. Frank Reynolds said he supported all his brother had stated.

45. Wragg Report in Meer, Documents, pp 254-255.

46. Thomas Reynolds died in June 1885. His sons, Charles and Frank, inherited the Umzinto estates.

47. Wragg Report in Meer, Documents, p 419 and p 538.

48. Wragg Report in Meer, Documents, pp 540-543.

49. Wragg Report in Meer, Documents, pp 279-280 and pp 329-331.

50. The Protector of Indian Immigrants noted in his report for 1907 that the suicide rate amongst indentured Indians in Natal was fourteen times greater than in India. Indian Opinion, 23 May 1908. 
The indifference of colonial society to that was well-illustrated by the writer of the "Notes from Umzinto" published in the Mercury on 13 October 1892. Amongst the news snippets was the following: "Last week, as usual, another coolie hanged himself on the Umzinto Estate." The writer subsequently sought to qualify what he had meant. He apologised for having used the term "as usual". What he had not meant, so he explained, was to convey the impression that suicides took place only on Umzinto Estate (which was owned by Reynolds Bros). ${ }^{51}$ From those words it is clear that there was no concern shown as to why suicides were occurring. The wording of the correspondent's November report on Umzinto demonstrated this emphatically. Under the heading "As Usual", he wrote: "Again, I have to report that a coolie has hanged himself in this county."

Between 1 July 1892 and 30 June 1893, the Protector of Indian Immigrants, Louis Mason, noted that eight Indians had committed suicide on Reynolds Bros estates. In each case the local magistrate had not found "reasonable grounds for the commitment of these acts". In the case of the most recent suicide, Charles Reynolds, the managing director, claimed that the man "continually absented himself and took to hiding in the fields for weeks". When Mason visited the Reynolds estates at Umzinto and Esperanza on 31 July 1893, he noted that the "field hands looked dirty in their persons and clothing. They had an unhappy look about them .... The women looked equally filthy and unhappy ... and to be thoroughly worn out". He also noted that indentured men were continually deserting from the Reynolds estates and concluded that the labourers "were not being given sufficient time to attend to domestic arrangements". ${ }^{3}$

Charles Reynolds' callous attitude towards his indentured labourers was shared by his brother, Frank who in 1895 became a director of Natal Sugar Estates and a member of the Indian Immigration Trust Board, the employers' agency for indentured labour. ${ }^{54}$ At a meeting of the board in June 1896, Frank Reynolds advocated stricter punitive action against indentured labourers for absence from roll call and desertion. Citing section 31 of Law 25 of 1891, Reynolds claimed that placing a convicted labourer on a spare diet or solitary confinement was not enough. ${ }^{55}$ It is significant that the members of the board concerned themselves only with punitive measures to deter desertion and failed to enquire as to the reasons indentured labourers sought to escape from sugar estates. Ironically, in the wake of Reynolds' call for draconian measures against deserters, several cases of desertion occurred from his estates in August $1896 .^{56}$ The reasons for desertion manifested themselves in October of that year when the

51. Natal Mercury, 22 October 1892.

52. Natal Mercury, 25 November 1892. For a study on Indian suicides, see Bhana and Bhana, "An Exploration of the Psycho-historical Circumstances surrounding Suicide", in Bhana (ed.), Essays on Indentured Indians, pp 137-189. Women received only half the wages and rations allotted to men.

53. PAR, Indian Immigration, 1/70/1893, 1196, 11 September 1893.

54. Indian Immigration Trust Board, Annual Report, 1896, p 1; Natal Mercury, 1 December 1896.

55. Natal Mercury, 15 June 1896.

56. Natal Mercury, 21 August 1896. In 1895, Reynolds Bros, with 752 Indian employees, was the largest employer of indentured labour on the South Coast. The second and third largest employers were Bazley \& Sons (with 113) and E.W. Hawksworth (with 72) respectively. Natal Government Gazette, XLVIII, No. 2736, 21 May 1895. 
Umzinto court heard seventeen cases of assault brought against two overseers and sirdars on a Reynolds sugar estate. One of the overseers had nine indictments brought against him. But eight of them were dismissed and on the remaining charge he was fined a mere £3. Desertion also troubled Hawksworth's Beneva estate in the Equeefa valley where 58 indentured labourers were brought to court in October $1896 .^{57}$

Desertions, suicides and the death rate on Reynolds Bros estates exceeded those on other estates while the general condition of the indentured labour employed by Reynolds Bros indicated overwork and poor health. ${ }^{58}$ Yet, following an inquiry in 1900 conducted by Louis Mason, the Protector of Indian Immigrants, assisted by Durban magistrate Herbert Miller, when a record 74 of the 1220 Indians employed on the Reynolds estates died during a ten month period a death rate of 60 per 1000 , at a time when the death rate in the colony was 15 per $1000,{ }^{59}$ the inquiry concluded that there was no evidence of "systematic abuse". Commenting on the findings of the inquiry, the attorney-general, Henry Bale, concurred that the numerous complaints of ill-treatment of indentured labour "were not justified". 60

The appointment of a new Protector of Indian Immigrants, James Polkinghorne in 1902, proved a turning point in the disregard shown by Reynolds Bros for the wellbeing of indentured workers on their estates. Polkinghorne visited the estates in the company of county medical officer, Dr W.P. Tritton and noted that indentured labourers were afflicted by overwork and poor quality of food. On 28 March 1905, in compiling an account of his efforts since 1902 to get Reynolds to rectify matters, Polkinghorne remarked that Reynolds routinely denied charges of overwork and poor food. ${ }^{61}$ Following a visit in August 1904, when he had received "many complaints" from Indians about ill-treatment, Polkinghorne warned Charles Reynolds that he had had "every opportunity ... to rectify matters". 62 Reynolds ignored the warning. In December 1904 Polkinghorne drew Reynolds' attention to the death rate on his estates of 36 per 1000 - double the colonial average - and specifically noted the poor hygiene, diet and domestic conditions of his labourers. ${ }^{63}$

57. Natal Mercury, 16 October 1896. Louis Mason, Protector of Indian Immigrants, noted that in cases where sirdars and overseers were charged with assault, witnesses were reluctant to come forward. "It is almost an impossibility to obtain evidence in support of complaints", he wrote with reference to the Chellan case in which Charles Reynolds was accused of assaulting an Indian named Chellan. See PAR, AGO 1/8/49, 3882, 2 August 1895.

58. Desai and Vahed, Inside Indian Indenture, pp 132-135. As Bhana notes in Essays on Indentured Indians ( $\mathrm{p}$ 137), the high suicide rate was "attributable to conditions under which indentured Indians lived and laboured".

59. PAR, CSO 2854, No. 7790, 1906. J.A. Polkinghorne's address to the Committee of Inquiry in Umzinto, p 2.

60. Desai and Vahed, Inside Indian Indenture, p 135; Mason and Miller based their findings on the examination of 608 men and 212 women. Protector of Indian Immigrants Report, 1900, Natal Blue Book, Departmental Reports, p A15.

61. PAR, CSO 2854, 7790, 28 March 1905. On a visit in August 1904, Polkinghorne found that workers had not received dholl and ghee rations for two months. (These items were critical in the nutritional diet of the workers). Reynolds denied this and claimed the rations were only ten days overdue. See PAR, CSO 2854, 7790, 28 March 1905.

62. PAR, CSO 2854, 7790, 30 August 1904.

63. PAR, CSO 2854, 7790, Polkinghorne's evidence to the 1906 Inquiry. 
Acting county medical officer Dr Gilroy confirmed in February 1905 that uncooked or partially cooked food (as a result of a lack of firewood and time to prepare meals) was causing diarrhoea which was a major cause of disease and death among Indians. Polkinghorne's visit on 21 and 22 February confirmed that excessive working hours were a major contributory factor to the poor condition of the Reynolds Bros workers. Whereas the contract for indentured labourers specified nine hours of labour six days a week, Polkinghorne established that Reynolds was getting an extra two days of labour a week from his workers by compelling them to be on duty before sunrise and beyond sunset particularly where those working in the mill were concerned. ${ }^{64}$ On 28 March 1905, Polkinghorne reported that the rice ration Reynolds provided to his labourers was inferior in quality and was purchased at up to two shillings less per bag. Polkinghorne requested the colonial secretary to suspend assignments of indentured labour to Reynolds until conditions on his estates were improved. ${ }^{65}$

Polkinghorne's unrelenting determination to end the exploitation of indentured labour on the Reynolds estates generated counter measures from Reynolds. On 8 May 1905, Dr Rouillard, the county medical officer, wrote to Polkinghorne declining to put in writing the opinions he had expressed to Polkinghorne verbally in August 1904, November 1904 and in January 1905 that indentured labourers on his estates were dying as a result of the food and treatment they received. Rouillard claimed that one of Reynolds' sub-managers, W.T. Pemberton, had asked him not to submit written testimony to Polkinghorne. ${ }^{66}$ Moreover, as Polkinghorne also noted, ${ }^{67}$ Rouillard was related to Reynolds in that Rouillard's brother was married to Reynolds' sister.

Besides having influence over the county medical officer, Reynolds also had influence over the resident magistrate, James McLaurin. Although McLaurin was transferred from Alexandra County to Camperdown in June $1905,{ }^{68}$ Reynolds obtained the following statement from McLaurin dated 3 November 1905, which Reynolds used in his defence during the 1906 Inquiry: "During the more than sixteen years I presided as Magistrate of Umzinto, I was comparatively little troubled by your estates and consider that, on the whole, your Indians were very well treated." In his report of 5 December 1905, Polkinghorne stated that McLaurin was "ill-advised to report" on the workings of the Reynolds estates because he "knew nothing" about the actual circumstances that prevailed. "Is this not another case of Mr Reynolds' influence?" Polkinghorne asked. ${ }^{69}$

Between 18 and 21 September 1905, Polkinghorne again visited the Reynolds estates and commented that inferior rice was still being given to the

64. PAR, CSO 2854, 7790, Polkinghorne's evidence to the 1906 Inquiry.

65. PAR, CSO 2854, 7790. Evidence to the 1906 Inquiry. Polkinghorne stated that he had contempt for the supplier of the rice, a Mr Thomson, who, despite twenty years of experience in the product, declined to comment on its quality. From that it may be concluded that Reynolds' influence and power was such that Thomson did not wish to risk remarks that might compromise his business relationship with Reynolds.

66. PAR, Indian Immigration 1/156, 8 May 1905; CSO 2854, 7790, Polkinghorne to Colonial Secretary, 25 May 1905.

67. PAR, CSO 2854, 7790, 5 December 1905.

68. Natal Mercury, 26 June 1905.

69. PAR, CSO 2854, 7790, 5 December 1905. 
labourers. He secured twelve depositions regarding overwork and a further twelve complaints of assault. Fear of victimisation prevented other labourers from coming forward. $^{70}$ As a result of Polkinghorne's September report, the top tier of government appeared to be rallying to his side. A communiqué from the Smythe ministry in October 1905 stated that ministers were of the opinion that unless "there was decided improvement in the treatment of Indians, no further allotment of Indians would be made to Reynolds Bros". ${ }^{71}$ This news caused Charles Reynolds to go on the offensive. He rejected the charges against him and requested "an impartial investigation", for which, he indicated, he was willing to pay, in order to vindicate himself. ${ }^{72}$

\section{The Reynolds Inquiry}

The colonial secretary ignored the offer made by Reynolds to finance an inquiry and invited three individuals to form a committee. They were: James Schofield a member of the legislative assembly (MLA) for Ixopo, Dr James Hyslop of the Natal Government Asylum and Mr C.B. Lloyd, who was commissioner of agriculture in the 1890 s and who served as chairman. ${ }^{73}$ The committee sat from January to April 1906. Initially Schofield attempted to restrict the scope of the inquiry to the period since 1902 when Polkinghorne became Protector. But Hyslop and Lloyd disagreed and as a result Polkinghorne was able to call on witnesses whose service on the Reynolds estates went back to $1884 .^{74}$ This proved critical in Polkinghorne's case because he was able to show that ill-treatment of Indian labour was institutionalised on the Reynolds estates. ${ }^{75} \mathrm{~F}$. Mellon who had served on three occasions as overseer - 1884 to 1890,1896 to 897 and 1899 to1900 - testified that working days started before sunrise and ended after sunset; that very little time was allowed for food consumption; and that no extra pay was given. E.B. Gautier who had been an overseer in the late 1890s corroborated evidence regarding the labourers' long working days, adding that he had seen Charles Reynolds striking workers when the boilers were not properly fired up and that Reynolds "would get into a temper" if asked to allow sick workers time off. ${ }^{76}$

Before going into law and becoming a practising advocate, Leon Renaud had been a supervisor in the Reynolds Bros mill from 1886 to 1894 . He also confirmed that overwork was routine. He testified that labourers had no time to cook their food properly which led to dysentery; that those who refused to work at night were thrashed; and that only when a worker collapsed was he taken to the medical officer. Renaud also contrasted the condition of Indians on the Reynolds

70. PAR, CSO 2854, 7790, 26 September 1905.

71. PAR, Indian Immigration, 1/156, 25 October 1905.The cosy relationship that Reynolds enjoyed with the colonial government was illustrated by the fact that when Governor Henry McCallum visited Alexandra County in September 1905, he stayed with Charles at the Reynolds' Lynton Hall mansion. See Natal Mercury, 25 September 1905.

72. PAR, CSO 2854, 7790, 1 November 1905. The inescapable implication of Reynolds' willingness to pay for an inquiry on charges of ill-treatment of indentured labour, is that he was prepared to buy a suitable outcome.

73. PAR, CSO 2854, 7990, 6 December 1905.

74. PAR, CSO 2854, 7790, Minutes of Committee of Inquiry 31 January, 8 February 1906.

75. PAR Indian Immigration, 1/70/1893, 1196, 11 September 1893. Protector Louis Mason noted the high desertion rate on Reynolds' estates and the fact that labourers appeared "worn out" and fatigued.

76. PAR, CSO 2854, 7790, 8 February 1906. 
estates with those on the neighbouring estates belonging to Hawkesworth and Kirkman. "You would have no doubt as to how the Indians are treated. You could see the difference", he stated. ${ }^{77}$ The former medical officer, Dr W.P. Tritton, also testified that working hours of labourers were excessive compared to other estates and that he had seen men working in the fields during downpours. ${ }^{78}$

In his testimony, Charles Reynolds proved evasive and disingenuous. He rejected the evidence of Gautier, Renaud and Mellon as having no bearing on the case because, he claimed, they had been dismissed for incompetence and unreliability. Instead he accused Polkinghorne of trying to ruin him through lies and misrepresentation and of acting in a "secret, underhand way" because Polkinghorne always spoke directly to the Indian labourers without being accompanied by managers. As to the high death rate on his estates, Reynolds claimed the calibre of labourers allotted to him were inferior to that of other estates and denied that his working hours were any different from those on other estates. $^{79}$

In support of Reynolds' testimony the Speaker of the legislative assembly and local MLA, Robert M. Archibald, told the inquiry that in his experience of 30 years in Alexandra County, dysentery and diarrhoea were promoted by droughts and bad water. He declined to say whether the labourers on the Reynolds estates were consuming "bad water". Also in support was the current medical officer Dr Rouillard. Performing a volte face from the opinions expressed in his letter of 8 May 1905, Rouillard informed the inquiry that he had never seen or had reason to suspect ill-treatment on the Reynolds estates. Under cross-questioning he proved evasive and forgetful. ${ }^{80} \mathrm{Mr}$ Drew, proprietor of the Alexandra Hotel in Umzinto, made it clear that concern for his livelihood was such that he was wary about giving evidence against Reynolds. ${ }^{81}$

In his address to the inquiry, Polkinghorne pointed out that it had been "common talk for many years that Mr Reynolds was a hard task master". Accusing Dr Rouillard of deceit, he noted that since Reynolds had been informed in October 1905 of the possibility of the government halting his procurement of further supplies of labour, there had been a dramatic improvement in the death rate on the estates; and that the rate (which was five and a half times lower than in the previous nine years) had coincided with the inquiry into conditions on the Reynolds estates. He went on to say: "I am perfectly aware that I am fighting a very strong and influential Company backed up in many quarters ... The Medical Officer has been against me, the whole neighbourhood has been against me." As if anticipating the outcome of the inquiry, he stated: "The question will not finish with

77. PAR, CSO 2854, 7790, 1906.

78. PAR, CSO 2854, 7790, 12 January 1906.

79. PAR, CSO 2854, 7790, February 1906. Reynolds' claim that he was allotted inferior labourers was spurious since his brother Frank had been on the Indian Immigration Trust Board since December 1895 and was replaced by Charles himself in December 1904. Since the Board was responsible for assigning indentured labourers, it was highly unlikely that the Reynolds brothers would have allotted themselves physically poor workers.

80. PAR, CSO 2854, 7790, 30 January 1906; 11 January 1906.

81. PAR, CSO 2854, 7790, 31 January 1906. 
this Committee. I shall carry it on further ... It is a question of the lives of these people and as Protector ... I found it my duty to take up this subject." ${ }^{82}$

Amongst the findings of the Reynolds Inquiry were: that the physical capacity of workers was exploited to the maximum; 50 percent of the deaths were attributable to illness and disease; workers were legally unable to obtain transfers between employers which induced a sense of helplessness; the shortage of women encouraged casual sexual relations which resulted in a high incidence of venereal disease. ${ }^{83}$ In their report, Hyslop and Lloyd endorsed Polkinghorne's case stating that if the death rate "again assumes its previous abnormal proportions, the allotments of Indians will be discontinued". But James Schofield presented a minority report in which he exonerated Reynolds of the charges brought. $^{84}$ Nonetheless, the political establishment declined to act on the compelling evidence which Polkinghorne had amassed. Three reasons may be adduced for that. First, the findings against Reynolds were eclipsed by the Bhambatha rebellion which caused widespread alarm and insecurity amongst settlers across the colony. ${ }^{85}$ As a result, there was reluctance to risk any further possible disruption of the labour supply as had occurred in 1871 when reports reached the India government of ill-treatment of indentured labourers in Natal and resulted in the suspension of indentured supplies until 1874. Second, the economic situation within Natal was precarious as a result of the ongoing depression $^{86}$. Disrupting production on the estates of the second largest producer of sugar in the colony by stopping its supply of indentured labour could not be financially contemplated. ${ }^{87}$ Third, political collusion at the highest levels ensured that the findings against Reynolds were hushed up and went unpublished.

Politically it had long been a reality that the flow of indentured labour was essential to the sugar industry. ${ }^{88}$ As such, anything which risked disruption of that flow was to be avoided as far as possible. The press also played a key role in the news blackout. Whereas in the 1890s the "Notes from Umzinto" column in the Mercury had made mention of indentured Indians committing suicide on the Reynolds estates, ${ }^{89}$ after 1892 , such reports or critical remarks appeared very rarely in the print media. An exception to that came in the form of a letter published in the Mercury in 1902 which stated, inter alia: "The planter, so long as his

82. PAR, CSO 2854, 7790, February 1906; 10 May 1906.

83. Bhana, Essays on Indentured Indians, p 148.

84. PAR, Indian Immigration, 1/156, 16 and 5 July 1908.

85. Natal Mercury, 1 March 1906; J. Lambert, "From Independence to Rebellion: African Society in Crisis 1880-1910", in A. Duminy and B. Guest (eds), Natal and Zululand from the Earliest Times to 1910: A New History (University of Natal Press, Pietermaritzburg, 1989), pp 389-394.

86. The Auditor-General's Report for $1906 / 07$ ( $p$ 6) noted a deficit of $£ 351,866$ in 1904/05 which increased to $£ 554,773$ by 1907 .

87. Hulett was the largest producer in 1908, followed by Reynolds Bros. See Natal Mercury, 28 November 1908.

88. On this subject, Natal Mercury editor, John Robinson, once stated that "we must always walk with the fear of the Indian authorities in our eyes" (7 June 1877).

89. Natal Mercury, 13 October, 25 November 1892. 
business is a success, shuts his eyes to, or connives at the cruel treatment which Indians receive." 90

Press silence also attended the work of the Reynolds Inquiry in $1906 .{ }^{91}$ The regular reports in the Mercury under the heading "Country Notes", were devoid of any news concerning the plight of indentured Indians in any of the country districts, although incidents of crime involving Indians were published. Gandhi's own newspaper, Indian Opinion, was part of that silence. As Maureen Swan has explained, in campaigning for equal rights for Indians, Gandhi focused on the merchants and traders rather than the indentured. ${ }^{92}$ The annual reports of the Indian Immigration Trust Board through to 1910 were also silent regarding the treatment of indentured labourers. Although the reports noted changes of representation on the board such as when Frank Reynolds replaced his brother, Charles, the report for $1908 / 1909$ gave no reason for that. Thus, it may be contended, that a conspiracy of silence prevailed concerning the exposure of labour exploitation.

As Protector of Indian Immigrants, James Polkinghorne showed courage and conviction. He simply refused to be obstructed and to neglect what he regarded as his primary function - the custodianship of the welfare of indentured Indians. ${ }^{93}$ In September 1906 he protested to the colonial secretary about having to continue assigning indentured labour to Reynolds when reports of ill-treatment persisted. ${ }^{94}$ In subsequent correspondence with the colonial secretary he urged that Governor McCallum "should be acquainted with the facts so the Indian government may be advised". ${ }^{95}$ The evidence Polkingorne provided to the Reynolds Inquiry did reach the governor of Madras, Sir Arthur Lawley, who then inquired confidentially about conditions for indentured labourers in Natal. McCallum placated his enquiry by claiming that the Reynolds case was "very exceptional". ${ }^{96}$

Between 24 and 26 September 1907, Polkinghorne again visited the Reynolds estates and noted that "matters had lapsed into their former bad state as regards overwork". He observed 200 Indians queuing for rations after $7 \mathrm{pm}$ while others were still loading cane trucks at that time. ${ }^{97}$ In a letter to Frank Reynolds he

90. Letter to the Editor, Natal Mercury, from "Natalian", 11 March 1902. In 1907 the Protector suggested that an inspector be appointed on the North Coast following many complaints about the ill-treatment of indentured labourers. See PAR, Indian Immigration, 1/155, 1907.

91. That silence extended to the issues of the Natal Agricultural Journal during the period 1900 to 1909.

92. M. Swan, Gandhi: The South African Experience (Ravan Press, Johannesburg, 1985), p 63.

93. Governor Henry McCallum described Polkinghorne as "most zealous". See also Warhurst, "Obstructing the Protector", p 38.

94. Desai and Vahed, Inside Indian Indenture, p 143

95. PAR, CSO 6270, 1907, cited in Desai and Vahed, Inside Indian Indenture, p 144.

96. Warhurst, "Obstructing the Protector", p 38. McCallum's response typifies the tendency of the colonial mind to play down human rights abuses to classes considered inferior. As a result of a dysentery epidemic in 1904, a death rate of 91 per 1000 occurred amongst indentured Indians on the Umhloti Valley Company estates; also on the Tongaat Sugar Company estates where a rate of 36 per 1,000 was recorded. See Bhana, Essays on Indentured Indians, p 141.

97. PAR, Indian Immigration, 1/156, 28 September 1907. 
expressed outrage that indentured labourers were working a twelve hour and often not getting any food until $9 \mathrm{pm}$. He slated the situation as one of "absolute cruelty". ${ }^{98}$ Yet still matters did not improve. Between November 1907 and the end of February 1908, there were 124 cases of diarrhoea and eight deaths on the Reynolds estates. According to Dr Ernest Hill, the health officer for Natal, "inferior mealie meal" caused the diarrhoea. ${ }^{99}$ In exasperation, on 1 June 1908 Polkinghorne wrote to the colonial secretary urging that Reynolds be charged with culpable homicide for the ongoing sickness and deaths of his indentured labourers as a result of diseased and fermented rations. "It is simply scandalous that such things should take place after the experience of the past", he exclaimed. ${ }^{100}$

While the Colonial Patriotic Union was busy whipping up settler emotions against continued Indian immigration to Natal in a series of meetings, ${ }^{101}$ the Natal government finally acted against Reynolds. Unobtrusively, in two separate letters, one dated 24 June and the other 2 July 1908, the colonial secretary informed Reynolds Bros that no further supplies of indentured labour would be assigned to their estates "so long as Mr C.P. Reynolds continues to be connected with its management". ${ }^{102}$ This request was not well-received by the management board of Reynolds Bros. In two letters, dated 15 July and 28 July 1908, the board demanded to know on what grounds Charles Reynolds was being targeted by the government so that he could rebut those charges. ${ }^{103}$ C.G. Smith, whose business interests included Reynolds Bros, was outraged by the demand for the removal of Charles Reynolds and retorted that in view of Polkinghorne's "animosity against Mr C.P. Reynolds", it would be better if the government dismissed Polkinghorne. ${ }^{104}$

But the government stood firm and in a memorandum dated 4 November 1908, the colonial secretary acknowledged that Charles Reynolds had left the Reynolds estates. In October, Frank Reynolds, who had assumed overall control of the business, assigned George Crookes of Renishaw to Charles' post. On 20 December 1908 Reynolds Bros received a new allotment of indentured labour. ${ }^{105}$ Throughout this time and those changes, a conspiracy of silence prevailed. Diligent and detailed news round-ups appeared in the Mercury's "Country Notes" columns and the Witness's "News of Country Districts". But news from Umzinto was conspicuous by its absence. Instead, the Witness found a financial controversy in the Cape Town City Council, called the "Mile End Scandal", more newsworthy. ${ }^{106}$ Moreover, the focus of the press in the last months of 1908 was taken up with the first National Convention meeting which began in Durban in

98. PAR, Indian Immigration, 1/156, 27 September 1907.

99. PAR, Indian Immigration, 1/157, 21 February 1908.

100. PAR, Indian Immigration, 1/156, 1 June 1908. Charles Reynolds left Natal in October 1906 for a six month vacation in Europe. See PAR, CSO 1820, 7265, 5 and 12 October 1906.

101. Well-attended meetings took place in the Durban Town Hall during the period from March 1907 to April 1908. Natal Mercury, 8 March 1907; 2 April 1908. The issue also featured at the Natal Farmers Conference in April 1908. Natal Mercury, 17 April 1908. The issue was also topical in the correspondence columns of the Mercury throughout 1907 and 1908.

102. PAR, Indian Immigration, 1/156.

103. PAR, Indian Immigration, $1 / 156$.

104. PAR, Indian Immigration, 1/156, 19 June 1908.

105. PAR, Indian Immigration, 1/156, 4 and 7 November 1908; and Desai and Vahed, Inside Indian Indenture, p 144.

106. Natal Witness, 10 and 11 August 1908. The 20-day trial resulted in the mayor receiving a two year gaol sentence. 
October; also the trial of Dinizulu in which he was charged, inter alia, with inciting the Bhambatha rebellion. ${ }^{107}$

An archival search of the records of the Colonial Secretary's Office, Attorney General's Office, Indian Immigration files and Prime Minister's Records does not yield any specific details concerning the Natal government's eventual action against Charles Reynolds. But a question posed on 30 July 1908 by a Durban Borough MLA, Charles Henry Haggar of the Labour Party to the colonial secretary and the response it elicited, is fairly enlightening. ${ }^{108}$ Haggar enquired how many employers of Indians during the past year had had their labourers taken away as a result of cruelty. He also asked how many employers had been threatened in consequence of their cruelty. The colonial secretary's terse response was: "Three in each case." ${ }^{109}$ Haggar did not ask who those employers were and therefore no names were disclosed. Nonetheless, the information provided does indicate that there was not only official awareness of the ill-treatment of indentured labour but that officialdom acted against it. In the case of Charles Reynolds, it was not that indentured Indians were taken from him. Instead he was removed from being involved in their management. Haggar's question was also ideologically significant. As a socialist his interest was in the welfare of labour while at the same time being critical of capitalists like the sugar barons. ${ }^{110}$

\section{Conclusion}

Polkinghorne's perseverance paid off. Charles Reynolds went into exile. ${ }^{111}$ But life carried on in the Umzinto district as if nothing had ever happened. Socially and politically the entire episode was a non-event. None of the six South Coast public representatives ${ }^{112}$ spoke out against Reynolds or raised motions of censure in the legislature. By their silence they effectively condoned Reynolds' exploitation of indentured labour. Yet it was a major scandal which eclipsed the complaints made by repatriated Indians in 1871 which led to the Coolie Commission of Inquiry of 1872. Although those complaints had concerned ill-treatment which included floggings and the inability of labourers to get their complaints heard by magistrates, desertions and suicides did not feature. ${ }^{113}$ As Polkinghorne wrote on 28 September 1907: "In my opinion, it is nothing short of absolute cruelty to treat

107. See J. Guy, Remembering the Rebellion: The Zulu Uprising of 1906 (University of KwaZulu Natal Press, Scottsville, 2006).

108. PAR CSO 1860, No. 4457, July 1908.

109. Natal Legislative Assembly, Votes and Proceedings, Vol. LXVII, 1908, p 262.

110. Haggar was listed as a member of the Social Democratic Federation based in Britain. See J. Edwards, The Labour Annual 1908: The Reformers Year Book (Forgotten Books Reprint, London, 2013), pp 74-75.

111. PAR, MSCE 1912, Vol. 45/94. C.P. Reynolds died in Mexico City on 12 February 1912. His estate was valued at $£ 60000$. The 1911 edition of the Natal Directory continued to list him as a resident of Umzinto ( $p$ 888).

112. Four sat in the Legislative Assembly: R.M. Archibald and J. Kirkman represented Alexandra County, C. Hitchens and P.A. Silburn for Alfred County. T. Kirkman and W. Hutchinson, respectively from Alexandra and Alfred Counties, sat in the upper house - the Legislative Council.

113. The complaints emanated from the 228 Indians aboard the Red Riding Hood. Similar complaints were not made by the 185 returning Indians aboard the Umvoti. See Thompson, "Indian Immigration," pp 118-119. 
Indians like this, and for what? Simply to be able to declare a larger dividend at the expense of human flesh."114

The financial and economic domination of Reynolds Bros also needs to be seen within the wider context of what might be called the "sugarocracy". As a director of Natal Estates, Frank Reynolds was in alliance with two North Coast sugar barons, David Don and Marshall Campbell. By 1904 the "sugarocracy" extended to Umzimkulu Estates on the lower South Coast where Frank Reynolds and C.G. Smith were among the major shareholders. ${ }^{115}$ From an imperial perspective, as Robert Johnson has remarked, political and economic conditions together with distinct legal and social structures favourable to settlers were the hallmark of colonial states. That privileging was premised on the ideological ranking of settlers over migrants and indigenous peoples. ${ }^{116}$ Thus, wealth in a small settler community was synonymous with status and power, and as such undoubtedly permeated all sections of settler society. Reynolds Bros influence as a business was such that it held sway over both the district medical officer and resident magistrate. The role of indentured labour in sugar production, the mainstay of the South Coast's economy, was simply taken for granted.

Overall, the Reynolds Bros case gives credence to Lorenzo Veracini's paradigm of a colonial situation, namely, one "characterised by settler capacity to control the population economy as a marker of a substantive type of sovereignty ... associated with a particular state of mind". ${ }^{117}$ It also manifested what Partha Chatterjee has termed "the triumphal colonial society", where coloniser and colonised knew and retained their respective places and where change was postponed. $^{118}$

\begin{abstract}
The pronouncements of the Coolie Commission of 1872 against the ill-treatment of indentured labour in the Natal Colony and the subsequent appointment of a Protector of Indian Immigrants did not deter certain employers from exploiting those indentured to them. Over a period of almost 25 years reports of assaults, desertions, deaths and suicides emanated from the Reynolds sugar estates in the Umzinto district. Yet a veneer of indifference, which evolved into a conspiracy of silence on the part of officialdom and civil society, served to protect the image of Reynolds Bros from censure. Moreover, within the ranks of the "sugarocracy" profits were prioritised ahead of human rights. This state of affairs was facilitated by the prevailing inherent ethnocentrism of the period. Thanks to the persistence of James Polkinghorne, as the Protector of Indian Immigrants, the extent of the abuse of human rights by Reynolds Bros was eventually exposed and appropriate remedial action taken.
\end{abstract}

114. PAR, Indian Immigration, 1/156, 28 September 1907. In this regard Desai and Vahed have commented that the Reynolds' "hands were soaked in the blood of indentured labourers". See Inside Indian Indenture, p 145.

115. P. Dickinson, "The Umzimkulu Sugar Company Ltd 1904-1940", The South African Journal of Economic History, 4, 1, March 1989, pp 21-23.

116. R. Johnson, British Imperialism: Histories and Controversies (Palgrave, Basingstoke, 2003), pp 60-62.

117. Veracini, Settler Colonialism, p 14.

118. Quoted in Veracini, Settler Colonialism, p 22. 
Keywords: Umzinto; Reynolds; Wragg Commission; Polkinghorne; sugar production; indentured labour; worker suicides.

\section{Opsomming}

Ten spyte van die uitsprake van die sogenaamde Coolie Commission van 1872 ten opsigte van die mishandeling van die inboekstelsel arbeiders in die Natalse Kolonie, asook die aanstelling van 'n Beskermer van Indiese Immigrante, het dit egter steeds nie sekere werkgewers daarvan weerhou om hulle ingeboekte arbeiders uit te buit nie. Oor 'n tydperk van bykans 25 jaar het berigte van aanrandings, drostery, sterftes en selfmoorde steeds voortgespruit uit die Reynolds suiker landgoed in die Umzinto distrik. Maar 'n skyn van onverskilligheid, wat mettertyd ontwikkel het in 'n sameswering van verswyging aan die kant van die amptenary asook die burgerlike samelewing, het egter gedien om die beeld van die Reynold broers te beskerm teen sensuur. Daarbenewens het winste voorrang geniet bo menseregte in die geledere van die "sugarocracy". Hierdie toedrag van sake was deur die heersende etnosentrisme van die tydperk vergemaklik. Danksy die volharding van James Polkinghorne, as Beskermer van die Indiese Immigrante, was die omvang van die skending van menseregte deur die Reynolds broers uiteindelik blootgestel en gevolglik was toepaslike regstellende aksie geneem.

Sleutelwoorde: Umzinto; Reynolds; Wragg Kommissie; Polkinghorne; suikerproduksie; inboekstelsel arbeiders; selfmoorde. 